\title{
Determinan Perilaku Pacaran Yang Beresiko Pada Siswa di SMKS YP Darul Mukminin Jatinegara Jakarta Timur Tahun 2020
}

\author{
Mozha Desri Puji Atuti dan Yeny Sulistyowati \\ Universitas Respati Indonesia \\ mozhadesri@yahoo.com
}

\begin{abstract}
Abstrak
Meningkatnya hubungan seksual sebagai salah satu penyebab masalah kesehatan reproduksi remaja Indonesia ditengarai akibat mudahnya mengakses informasi material seksual antara lain melalui internet. Hubungan seksual sebagai perilak berisiko saat ini dianggap biasa oleh remaja yang berpacaran. Komisi Perlindungan Anak Indonesia (KPAI) menemukan 62,7\% remaja di Indonesia sudah melakukan hubungan seksual. Remaja saat ini menganggap hubungan seksual merupakan hal yang biasa ketika berpacaran. Penelitian ini bertujuan untuk mempelajari dan menjelaskan determinan perilaku pacaran yang beresiko pada siswa di satu sekolah Islam di Jakarta. Metode penelitian ini menggunakan pendekatan kuantitatif, non eksperimental. Peneliti menggunakan metode survai analitik dengan rancangan cross sectional yang dilaksanakan bulan 02 Maret 2020 sampai 15 agustus 2020 penelitian dilaksanakan di SMKS YP Darul Mukminin Jatinegara. Popolasi dalam penelitian ini 221 siswa perhitungan besar sampel dilakukan dengan menggunakan rumus Slovin,sehingga total sempel 145, instrumen yang digunakan dalam penelitian ini menggunakan data skunder dan data primer. Hasil penelitian ini menunjukan siswa di SMKS YP Darul Mukminin Jatinegara Jakarta timur tahun 2020 mendapatkan bahwa Sekitar siswa (24,8\%) memiliki perilaku seksual berisiko dan Sekitar siswa $(75,2 \%)$ memiliki perilaku seksual tidak berisiko. serta variabel yang mempunyai hubungan dengan perilaku seksual beresiko dari variable independen yaitu Pengetahuan, jenis kelamin, tempat tinggal, status pacaran dan pengaruh teman sebaya. faktor yang paling dominan adalah teman sebaya dengan ( $P$-value $=0,462 ; O R 2,6 ; C l(0,197-35,525)$. Kesimpulan walaupun tidak bermakna secara statistik, variabl yang dominan berhubungan dengan perilaku pacaran beresiko adalah teman sebaya, setelah dikontrol oleh variabel pengetahuan, Jenis kelamin, Status pacaran dan tempat tinggal.
\end{abstract}

Kata Kunci : Perilaku, Pacaran, Beresiko

Abstract
The increase in sexual relations as one of the causes of reproductive health problems for Indonesian adolescents is suspected to be the result of easy access to sexual material information, among others via the internet. Currently dating as a risky sexual relationship is considered normal by teenagers. The Indonesian Child Protection Commission (KPAl) found $62.7 \%$ of adolescents in Indonesia have had sexual intercourse. Teens today consider sexual relations to be common when dating. This study aims to study and explain the determinants of risky dating behavior in students at an Islamic school in Jakarta. This research method uses a quantitative, non-experimental approach. Researchers used an analytical survey method with a cross sectional design which was carried out from March 2, 2020 to August 15, 2020, the study was conducted at YP Darul Mukminin Jatinegara Senior High School. Popolation in this study by 221 students, the sample size calculation was carried out using the Slovin formula, so that the total sample was 145 , the instrument used in this study used secondary data and primary data. The results of this study show that students at YP Darul Mukminin Jatinegara Junior High School, East Jakarta in 2020 found that around students $(24,8.2 \%)$ had risky sexual behavior and approximately of students (75.2\%) have risky sexual no behavior as well as variables that have a relationship with risky sexual behavior from the independent variables, namely knowledge, gender, place of residence, dating status and peer influence. The most dominant factor is peers with the (P-value $=0,462 ; \mathrm{OR} 2,6 ; \mathrm{Cl}(0,197-35,525)$. Conclusion, although not statistically significant, the dominant variable associated with risk courtship behavior is peers, after being controlled by the variables of knowledge, gender, dating status and residence.

Key words: Behavior, Courtship, Risky

http://ejournal.urindo.ac.id/index.php/kesehatan

Article History :

Sumbitted 02 November 2021, Accepted 25 Desember 2021, Published 31 Desember 2021 


\section{A. PENDAHULUAN}

Perilaku seksual merupakan segala tingkah laku yang didorong oleh hasrat seksual, baik dengan lawan jenis maupun sesama jenis, bentuk tingkah laku bisa bermacam-macam, mulai dari perasaan suka sampai tingkah laku berkencan, bercumbu, dan berhubungan intim. Objek seksualnya bisa berupa orang lain, orang dalam khayalan, atau diri sendiri. ${ }^{1}$ Pacaran dapat menjadi konteks untuk melakukan esperimen dan eksplorasi seksual, bentuk esperimen dan eksplorasi seksual yang marak dikalangan remaja Indonesia saat ini adalah melakukan hubungan seksual pranikah. $^{2}$

Menurut WHO, remaja adalah penduduk dalam rentang usia 10-19 tahun, menurut Peraturan Menteri Kesehatan RI Nomor 25 tahun 2014, remaja adalah penduduk dalam rentang usia 10-18 tahun dan Menurut Badan Kependudukan dan Keluarga Berencana (BKKBN) rentang usia remaja adalah 10-24 tahun dan belum menikah. ${ }^{3}$

Badan Koordinasi Keluarga Berencana Nasional (BKKBN) mendapatkan 46\% remaja berusia 15-19 tahun sudah berani melakukan hubungan seksual pranikah (bkkbn.go.id, 2014). Komisi Perlindungan Anak Indonesia (KPAI) mendapati bahwa 62,7\% remaja di Indonesia sudah tidak perawan. BKKBN mencatat meningktanya kasus hubungan seksual di kalangan remaja Indonesia akibat mudahnya mengakses informasi mengenai masalah seksual melalui internet. Remaja saat ini sudah menganggap hubungan seksual merupakan hal yang biasa dilakukan ketika remaja sedang berpacaran. ${ }^{4}$

Ramainya perederan video porno dan mudahnya mengaskes internet mengenai seksual membuat remaja dengan mudah mendapatkan informasi mengenai seksualitas. Remaja yang sering melihat pornografi dengan mudah akan melakukan hubungan seksual pranikah dan dapat menjadi korban atau pelaku kekerasan seksual. Hubungan seksual pranikah memiliki dampak buruk bagi remaja, yaitu resiko terkena penyakit menular seksual (seperti HIV/AIDS, gonore, sifilis, dan herpes genitalis), kehamilan yang tidak diinginkan oleh remaja putri, dan trauma kejiwaan (Tim Penulis Poltekkes Departemen Kesehatan, 2012). Data yang diperoleh dari Kementerian Kesehatan, pada tahun 2012 terdapat kasus HIV sebanyak 21.511 orang dan AIDS 5.686 orang. ${ }^{5}$

Provinsi DKI Jakarta berusia penduduk muda (usia 0-14 th) relatif lebih banyak jika dibandingkan dengan penduduk usia diatasnya. Survey Kesehatan Reproduksi Remaja Indonesia (SKRRI) tahun 2012, menyatakan 28 persen dari remaja pria dan 27 persen remaja wanita menyatakan bahwa mereka memulai berpacaran sebelum berumur 15 tahun, sedangkan menurut SKKRI tahun 2007 hanya 19 persen remaja yang pria dan 24 persen remaja wanita. Peningkatan ini menegaskan bahwa makin banyak remaja yang telah mulai berpacaran. ${ }^{6}$ Ada perbedaan nyata pada umur mulai berpacaran pada remaja berumur 12-14 tahun pada SDKI 2012 KRR dibandingkana dengan SKRRI tahun 2007. Pada tahun 2012, sejumlah 25 persen remaja pria dan 
26 persen remaja wanita memulai berpacaran pada umur 12 sampai dengan 14 tahun, sementara pada tahun 2007, 15 persen remaja pria dan 20 persen remaja wanita memulai berpacaran pada umur yang sama. Hal ini menegaskan bahwa remaja mulai berpacaran pada umur yang lebih muda. SKRRI. ${ }^{6}$

Hasil studi pendahuluan dengan menggunakan wawancara pada siswa tanggal 2 Maret 2020 pada 10 orang siswa 8 orang siswa menjawab pernah melakukan ciuma dengan pacarnya/lawan jenis di sekolah saat pulang sekolah. Menurut mereka sudah wajar jika sepasang kekasih berpegangan tangan, merangkul dan berciuman apalagi sekolahan berada $d$ tengah kota sehinga bisa berpergian ke kebioskop dan cafe.

Tujuan penelitian ini adalah untuk mempelajari

dan menjelaskan determinan faktor perilaku pacaran yang beresiko pada siswa di SMKS YP Darul Mukminin Jatinegara Jakarta Timur tahun 2020.

\section{B. METODE PENELITIAN}

\section{Jenis dan Rancangan Penelitian}

Penelitian ini menggunakan pendekatan kuantitatif, non eksperimental. Peneliti menggunakan metode survai analitik dengan rancangan cross sectional yaitu variabel sebab (independen) maupun variabel akibat (dependen) diobsevasi sekaligus pada waktu yang sama. ${ }^{7}$

\section{Lokasi dan Waktu Penelitian}

Waktu penelitian ini dilaksanakan dari bulan 02 Maret 2020 sampai 15 agustus 2020 penelitian dilaksanakan di SMKS YP Darul Mukminin Jatinegara.

Lokasi penelitian yang digunakan dalam penelitian ini adalah di SMKS YP Darul Mukminin Jatinegara.

\section{Populasi dan Sampel}

Populasi dalam penelitian ini adalah siswa siswi kelas 10 dan kelas 11 di SMKS YP Darul Mukminin Jatinegara yang berjumlah 221.

Sampel Penelitian dianggap mewakili seluruh populasi. Karena besar populasi sudah diketahui sebelumnya maka perhitungan besar sampel dilakukan dengan menggunakan rumus Slovin.besar sempel adalah 145.

\section{Cara Pengumpulan Data}

Data primer berasal dari sumber asli ataupun pertama dan diperoleh dari penyebaran kuisoner kepada siswa di SMKS YP Darul Mukminin Jatinegara. Pengumpulan data dilakukan oleh peneliti dan seorang guru yang ditunjuk oleh kepala sekolah untuk mendapingi.

Data sekunder berasal dari pihak kedua atau bukan data yang datang secara langsung, data ini mendukung pembahasan dan penelitian, untuk itu beberapa sumber buku atau data yang di peroleh digunakan untuk membantu dan mengkaji secara kritis penelitian tersebut. Data lainnya diperoleh dari buku-buku, brosur dan artikel yang di dapat dari website yang berkaitan dengan penelitian ini. Untuk memperoleh data ini peneliti mengambil sejumlah buku-buku, brosur, website, dan contoh penelitian sebelumnya yang berkaitan dengan penelitian ini. 


\section{Intrument Penelitian}

Data primer diperoleh secara langsung dari obyek penelitian melalui kuesioner. ${ }^{8}$

\section{Analisi Data}

Analisis univariat dilakukan oleh peneliti untuk mengetahui distribusi frekuensi dan variabel independen/dependen. Setelah pengolahan data selanjutnya dilakukan analisis dengan analisis univariat. Analisis univariat dilakuakan untuk mengetahui proporsi dan distribusi frekuensi dari masing-masing variabel yang diteliti.

Analisis bivariat dilakukan untuk melihat dua variabel yang diduga berhubungan atau berkolerasi. Uji statistik yang dilakukan uji khi- kuadrat (chi-cquare) karena data yang digunakan adalah data katagorik, dengan bantuan perangkat lunak, program statistik, dihasilkan Odds Ratio yang digunakan untuk menghasilkan hubungan antara dua variabel yang diteliti.

Analisis multivariat dilakukan untuk meliat variable independen yang paling berpengaruh terhadap variabel dependen. Analisis multivariat yang digunakan adalah regresi logistic model prediksi, dengan tingkat kepercayaan 95\% dan menggunakan metode menentukan odds ratio variabel katagorik polikontom dengan salah satu katagori menjadi pembanding dengan cara shi square. ${ }^{9}$

\section{HASIL DAN PEMBAHASAN}

\section{Hasil Analisis Univariat}

\begin{tabular}{|c|c|c|c|}
\hline No & Variabel & Freskuensi & Persentase (\%) \\
\hline \multirow[t]{3}{*}{1} & Perilaku & & \\
\hline & Tidak beresiko & 109 & 75,2 \\
\hline & Beresiko & 36 & 24,8 \\
\hline \multirow[t]{3}{*}{2} & Pengetahuan & & \\
\hline & Cukup & 98 & 67,6 \\
\hline & Tidak cukup & 47 & 32,4 \\
\hline \multirow[t]{3}{*}{3} & Sikap & & \\
\hline & Tidak setuju & 59 & 40,7 \\
\hline & Setuju & 86 & 59,3 \\
\hline \multirow[t]{3}{*}{4} & Jenis Kelamain & & \\
\hline & Perempuan & 95 & 65,5 \\
\hline & Laki-Laki & 50 & 34,5 \\
\hline \multirow[t]{3}{*}{5} & Tempat Tinggal & & \\
\hline & Di rumah orang tua & 102 & 73,3 \\
\hline & Di luar rumah & 43 & 29,7 \\
\hline \multirow[t]{3}{*}{6} & Status Pacaran & & \\
\hline & Tidak berpacaran & 103 & 71,0 \\
\hline & Berpacaran & 42 & 29,0 \\
\hline \multirow[t]{3}{*}{7} & Kontrol Orang Tua & & \\
\hline & Di control & 71 & 49,0 \\
\hline & Tidak di kontrol & 74 & 51,0 \\
\hline
\end{tabular}




\section{Jurnal Bidang IImu Kesehatan}

\begin{tabular}{llrl}
\hline 8 & Informasi Pendidikan Kesehatan & & \\
& Iya ada & 57 & 39,3 \\
& Tidak ada & 88 & 60,7 \\
\hline $\mathbf{9}$ & Teman Sebaya & & \\
& Tidak terpengaruh & 95 & 65,5 \\
$\quad$ Terpengaruh & 50 & 34,5 \\
\hline $\mathbf{1 0}$ & Pengaruh Media Informasi & & \\
& Tidak terpengaruh & 74 & 51,0 \\
& Terpengaruh & 71 & 49,0 \\
\hline
\end{tabular}

\section{Analisis Bivariat}

\begin{tabular}{|c|c|c|c|c|c|c|c|c|c|c|}
\hline \multirow[t]{3}{*}{ No } & \multirow[t]{3}{*}{ Variabel } & \multicolumn{4}{|c|}{ Perilaku Pacaran Yang Beresiko } & \multicolumn{2}{|c|}{ Total } & \multirow{3}{*}{$\begin{array}{c}\text { P } \\
\text { Value }\end{array}$} & \multirow[t]{3}{*}{ OR } & \multirow[t]{3}{*}{ 95\%Cl } \\
\hline & & \multicolumn{2}{|c|}{ Tidak Beresiko } & \multicolumn{2}{|c|}{ Beresiko } & \multirow[b]{2}{*}{$\mathrm{n}$} & \multirow[b]{2}{*}{$\%$} & & & \\
\hline & & $\mathrm{N}$ & $\%$ & $\mathrm{n}$ & $\%$ & & & & & \\
\hline 1 & Pengetahuan & & & & & & & \multirow{3}{*}{0,034} & \multirow{3}{*}{0,332} & \multirow{3}{*}{$0,127-0,865$} \\
\hline & Cukup & 68 & 69,4 & 30 & 30,6 & 98 & 100 & & & \\
\hline & Tidak Cukup & 41 & 87,2 & 6 & 12,8 & 47 & 100 & & & \\
\hline \multirow[t]{3}{*}{2} & Sikap & & & & & & & \multirow{3}{*}{0,401} & \multirow{3}{*}{1,516} & \multirow{3}{*}{$0,668-3,340$} \\
\hline & Tidak Setuju & 47 & 79,7 & 12 & 20,3 & 59 & 100 & & & \\
\hline & Setuju & 62 & 72,1 & 24 & 27,9 & 86 & 100 & & & \\
\hline \multirow[t]{3}{*}{3} & Jenis kelamin & & & & & & & \multirow{3}{*}{0,017} & \multirow{3}{*}{0,295} & \multirow{3}{*}{$0114-0,769$} \\
\hline & Prempuan & 65 & 68,4 & 30 & 31,6 & 95 & 100 & & & \\
\hline & Laki-Laki & 44 & 88,0 & 6 & 12,0 & 50 & 100 & & & \\
\hline \multirow[t]{3}{*}{4} & Tempat tinggal & & & & & & & \multirow{3}{*}{0,029} & \multirow{3}{*}{0,301} & \multirow{3}{*}{$0,108-0,839$} \\
\hline & Dirumah orang tua & 71 & 69,6 & 31 & 30,4 & 102 & 100 & & & \\
\hline & Diluar rumah orang tua & 38 & 88,4 & 5 & 11,6 & 43 & 100 & & & \\
\hline \multirow[t]{3}{*}{5} & Status pacaran & & & & & & & \multirow{3}{*}{0,037} & \multirow{3}{*}{0,314} & \\
\hline & Tidak berpacaran & 72 & 69,9 & 31 & 30,1 & 103 & 100 & & & $0,113-0,874$ \\
\hline & Berpacaran & 37 & 88,1 & 5 & 11,9 & 42 & 100 & & & \\
\hline 6 & Kontrol orang tua & & & & & & & & & \\
\hline & iya dikontrol & 55 & 77,5 & 16 & 22,5 & 71 & 100 & 0,665 & 1,273 & $0,597-2,714$ \\
\hline & Tidak dikontrol & 54 & 73,0 & 20 & 27,0 & 74 & 100 & & & \\
\hline 7 & Informasi Pendidikan & & & & & & & & & \\
\hline & $\begin{array}{l}\text { Kesehatan di Sekolah } \\
\text { Iya ada }\end{array}$ & 41 & 71,9 & 16 & 28,1 & 57 & 100 & 0,596 & 0,754 & $0,351-1,617$ \\
\hline & Tidak ada & 68 & 77,3 & 20 & 22,7 & 88 & 100 & & & \\
\hline 8 & Teman sebaya & & & & & & & & & \\
\hline & Tidak terpengaruh & 66 & 69,5 & 29 & 30,5 & 95 & 100 & 0,047 & 0,370 & $0,149-0,921$ \\
\hline & Terpengaruh & 42 & 86,0 & 7 & 14,0 & 50 & 100 & & & \\
\hline 9 & $\begin{array}{l}\text { Pengaruh media } \\
\text { informasi }\end{array}$ & & & & & & & & & \\
\hline & Tidak terpengaruh & 56 & 75,7 & 18 & 24,3 & 74 & 100 & 1,000 & 1,057 & $0,497-2,245$ \\
\hline & Terpengaruh & 53 & 74.6 & 18 & 25,4 & 71 & 100 & & & \\
\hline
\end{tabular}




\section{PEMBAHASAN}

\section{Gambaran Perilaku Pacaran Yang}

Berisiko Pada Siswa Di SMKS YP Darul Mukminin Jatinegara Jakarta Timur Tahun 2020

Berdasarkan hasil penelitian dari 145 responden menunjukkan bahwa sebesar 109 $(75,2 \%)$ memiliki perilaku pacaran yang tidak berisiko dan sebanyak 36 (24,8\%) memiliki perilaku pacaran yang berisiko.

Menurut teori Iwan (2010) pacaran adalah salah satu aktivitas yang banyak dijalani oleh remaja. Perkembangan psikologis pada masa remaja. Perkembangan psikologis pada masa remaja memungkinkan adanya ketertarikan terhadap lawan jenis dan keinginan untuk membentuk hubungan yang lebih dari sekedar teman atau sahabat. ${ }^{10}$

Penelitian ini mendapat hasil yang sama dengan penelitian mahmudah di Sumatra barat (2016). Gambaran perilaku pacaran remaja di Kota Padang dengan hasil Remaja yang berperilaku seksual berisiko $(20,9 \%)$ dan remaja yang berperilaku seksual tidak berisiko $(79,1 \%)$. Jenis penelitian ini adalah analitik dengan desain cross sectional. Jumlah sampel dalam penelitian ini adalah 158 orang yang diambil dengan cara multistage random sampling. Analisis data dilakukan dengan uji chi square dengan tingkat kemaknaan 95\%."

Menurut peneliti gambaran perilaku pacaran yang beresiko disebabkan karena kurang paham akan pengetahuan seksual beresiko yaitu Pengetahuan tentang kesehatan reproduksi seperti sistem reproduksi, fungsi, prosesnya dan cara-cara pencegahan/penanggulangan terhadap kehamilan, aborsi, penyakit-penyakit kelamin. Selain itu, remaja yang kurang pengetahuan mengenai perilaku seksual beresiko . Beberapa anggapan yang salah tentang hubungan seksual diantaranya adalah kehamilan tidak mungkin terjadi bila hubungan seksual hanya dilakukan satu kali, hanya dilakukan diusia muda. Hal ini bisa terjadi pada beberapa siswa remaja yang pernah atau sedang memiliki pacar sehingga mendukung akan perilaku seksual beresiko.

\section{Hubungan Pengetahuan Dengan} Perilaku Pacaran Yang Berisiko pada Siswa Di SMKS YP Darul Mukminin Jatinegara Jakarta Timur Tahun 2020

Berdasarkan hasil penelitian bahwa antara pengetahuan dengan perilaku pacaran yang berisiko pada siswa didapatkan, Hasil uji chisquare diperoleh nilai $p$ value 0,034 maka dapat disimpulkan ada hubungan yang signifikan antara pengetahuan dengan perilaku pacaran yang berisiko. Diperoleh nilai OR 0,332 yang artinya siswa yang berpengatahuan cukup mempunyai risiko untuk berperilaku pacaran yang beresiko 0,3 kali lebih besar dibandingkan siswa yang berpengetahuan tinggi.

Menurut teori Notoatmodjo (2012) Pengetahuan tentang kesehatan reproduksi mencakup apa yang diketahui oleh seseorang terhadap kesehatan reproduksi seperti sistem reproduksi, fungsi, prosesnya dan cara-cara pencegahan/penanggulangan terhadap kehamilan, aborsi, penyakit-penyakit kelamin. ${ }^{8}$ Penelitian ini mendapat hasil yang sama dengan penelitian Harni Andriani, Yasnani, Arum yang di Kendari (2016). Mengenai hubungan 
pengetahuan dengan perilaku pacaran yang beresiko. Hasil uji statistik Chi-Square pada taraf kepercayaan $95 \%(\alpha=0,05)$ menunjukan bahwa $\rho$ Value $=0,030$, jadi $\rho$ Value $<\alpha(0,05)$ sehingga Ho ditolak dan Ha diterima, artinya ada hubungan pengetahuan dengan perilaku pacaran remaja di SMK Negeri 1 Kendari. ${ }^{12}$

Menurut peneliti ini dari hasil penelitian adanya hubungan pengetahuan dengan perilaku pacaran yang berisiko pada siswa dikarenakan pengetahuan diperlukan untuk menghasilkan suatu perilaku tertentu ketika menghadapi suatu keadaan tertentu. Remaja yang memiliki pengetahuan secara benar tentang kesehatan reproduksi cenderung memahami prilaku pacaran serta alternatif cara yang dapat digunakan untuk menyalurkan dorongan seksual secara sehat dan bertanggung jawab. Sehingga pengetahuan seksual beresiko berhubungan dengan perilaku pacaran yang beresiko karena adanya rasa tahu mengenai pengetahuan seksual beresiko mendorong siswa tersebut untuk melakukan perilaku pacaran yang beresiko.

\section{Hubungan Sikap Dengan Perilaku} Seksual Berisiko Pada Siswa Di SMKS YP Darul Mukminin Jatinegara Jakarta Timur Tahun 2020

Berdasarkan hasil penelitian bahwa antara sikap dengan perilaku pacaran yang berisiko pada siswa didapatkan Hasil uji chisquare diperoleh nilai $p$ value 0,401 maka dapat disimpulkan tidak ada hubungan yang signifikan antara sikap dengan perilaku seksual berisiko.

Menurut Notoatmojo (2012), yang menjelaskan bahwa sikap merupakan reaksi atau respon seseorang yang masih tertutup dari seseorang terhadap suatu stimulus atau obyek. Manifestasi sikap itu tidak dapat langsung dilihat tetapi hanya dapat menafsirkan terlebih dahulu dari perilaku yang tertutup, sikap secara nyata menunjukkan konotasi adanya kesesuaian reaksi terhadap stimulus tertentu yang dalam kehidupan sehari-hari merupakan reaksi yang bersifat emosional terhadap stimulus social. ${ }^{8}$

Penelitian ini berbeda dengan penelitian Nadra anniswah (2016). Mengenai hubungan sikap dengan perilaku pacaran yang beresiko. Yang tertera pada hasil remaja yang bersifat negative lebih banyak berperilaku pacaran yang beresiko (24\%) disbanding remaja yang bersikap positif $(2,7 \%)$. Berdasarkan hasil analisis bivariate di peroleh $p$ volue 0,000 yang berarti terdapat Hubungan signifikan antara sikap dengan prilaku pacaran yang beresiko. ${ }^{13}$

Menurut peneliti dari hasil penelitian tidak ada hubungan sikap dengan perilaku pacaran yang berisiko pada siswa Hal ini di karenakan tindakan merupakan suatu kegiatan atau aktivitas manusia, baik dapat diamati secara langsung maupun tidak dapat diamati oleh pihak luar. Dimana tindakan/perilaku terdiri dari persepsi, respon terpimpin, mekanisme, adaptasi. $^{8}$

\section{Hubungan Jenis Kelamin Dengan} Perilaku Pacaran Yang Berisiko pada Siswa Di SMKS YP Darul Mukminin Jatinegara Jakarta Timur Tahun 2020

Berdasarkan hasil penelitian bahwa antara jenis kelamin dengan perilaku pacaran yang berisiko pada siswa didapatkan, Hasil uji chisquare diperoleh nilai $p$ value 0,017 maka dapat 
disimpulkan ada hubungan yang signifikan antara pengetahuan dengan perilaku pacaran yang berisiko. Diperoleh nilai OR 0,295 yang artinya siswa yang jenis kelami laki-laki mempunyai risiko untuk berperilaku pacaran yang beresiko 0,2 kali lebih besar dibandingkan siswa yang jenis kelamin prempuan.

Menurut Saifudin (2014), Dalam perilaku seksual, terdapat perbedaan antara jenis kelamin perempuan dan jenis kelamin laki-laki. Perbedaan ini disebabkan oleh faktor biologis dan sosial. Secara biologis laki-laki lebih mudah terangsang dan mengalami ereksi di banding perempuan. Secara sosial laki-laki cenderung lebih bebas di banding perempuan dan orang tua cenderung lebih protektif pada remaja perempuan, sehingga laki-laki akan lebih mudah melakukan hubungan

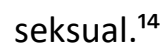

Penelitian ini sama dengan penelitian Putu agung raditya dan $\mathrm{Ni}$ wayan citra wulan di wilayah puskesmas sukawati (2016). Mengenai hubungan jenis kelamin dengan prilaku seks pranikah yang tertera pada hasil $26,3 \%$ lelaki dalam penelitian ini telah melakukan perilaku seks pranikah, Sedangkan 5,6\% prempuan telah melakukan perilaku seks pranikah nilai $p$ value dalam penelitian ini adalah 0,011yang berarti jenis kelamin mempunyai hubungan yang sangat segnifikan dengan perilaku seks pranikah nilai OR 3,631 yang berarti lelaki mempunyai faktor resiko dari prilaku seks pranikah. ${ }^{15}$

Menurut peneliti ini dari hasil penelitian adanya hubungan jenis kelamin dengan perilaku pacaran yang berisiko pada siswa dikarenakan laki - laki lebih banyak melakukan perilaku pacaran yang beresiko,laki - laki lebih suka melakukan fantasi seksual,menonton video porno dan berbicara perilaku seksualnya ke temannya. Faktor biolagis juga berperan terhadap laki - laki lebih banyak melakukan hubungan pacaran yang beresiko. Pada laki - laki, hormon testosterone juga berperan dalam hal ini. Pada perempuan diperlukan banyak hormon testosterone dalam meningkatkan perilaku seksualnya, sedangkan pada laki - laki hanya perlu sedikit.

\section{Hubungan Tempat Tinggal Dengan} Perilaku Pacaran Yang Berisiko Pada Siswa Di SMKS YP Darul Mukminin Jatinegara Jakarta Timur Tahun 2020

Berdasarkan hasil penelitian bahwa antara tempat tinggal dengan perilaku pacaran yang berisiko pada siswa didapatkan Hasil uji chisquare diperoleh nilai $p$ value 0,029 maka dapat disimpulkan ada hubungan yang signifikan antara tempat tinggal dengan perilaku pacaran yang berisiko. Diperoleh nilai OR 0,301 yang artinya siswa yang bertempat tidak tinggal di rumah orang tua mempunyai risiko untuk berperilaku pacaran beresiko 0,3 kali lebih besar dibandingkan siswa tempat tinggal di rumah orang tua nya.

Menurut teori PKBI (2015) tempat tinggal adalah sebuah tempat yang biasanya berwujud bangunan rumah, tempat berteduh, atau struktur lainnya yang digunakan sebagai tempat manusia tinggal. Tempat lokasi paling sering melakukan perbuatan terlarang tersebut bersama pacar adalah di rumah dan di tempat kost. ${ }^{16}$

Penelitian ini mendapat hasil yang sama dengan penelitian Erna mesra (2016). Mengenai 
Tempat Tinggal dengan Perilaku pacaran Berisiko di Jakarta. Hasil penelitian Tempat tinggal berhubungan bermakna dengan perilaku pacaran. Tempat tinggal yang tidak kodusif memiliki perilaku seksual berat sebanyak $73.9 \%$ sedangkan lingkungan tempat tinggal yang kondusif memiliki perilaku seksual tergolong berat sebanyak $43.9 \%{ }^{17}$

Menurut peneliti dari hasil penelitian tidak ada hubungan tempat tinggal dengan perilaku pacaran yang berisiko pada remaja dikarenakan tinggal di luar rumah orang tua seperti kosan atau ruma soudara selalu bebas mau ngapain begituju juga bawa pacar maen karna tidak ada yg memperhatikan, sehingga mudah untuk melakukan perilaku pacaran yang beresiko, apabila kostan sepi atau tidak ada yang mengawasi remaja cenderung berani untuk melakukan hubungan seksual.

\section{Hubungan Status Pacaran Dengan} Perilaku pacaran Yang Berisiko Pada Siswa Di SMKS YP Darul Mukminin Jatinegara Jakarta Timur Tahun 2020

Berdasarkan hasil penelitian bahwa antara status pacaran dengan perilaku pacaran yang berisiko pada siswa didapatkan Hasil uji chisquare diperoleh nilai $p$ value 0,037 maka dapat disimpulkan ada hubungan yang signifikan antara status pacaran dengan perilaku seksual berisiko. Diperoleh nilai OR 0,314 yang artinya siswa yang yang berpacaran mempunyai risiko untuk berperilaku pacaran yang beresiko 0,3 kali lebih besar dibandingkan siswa yang tidak berpacaran.

Menurut iwan (2010). Pacaran adalah sebagai proses perkembangan kepribadian seorang remaja, karena ketertarikan terhadap lawan jenis namun demikian dalam perkembangan budaya justru cenderung permisif terhadap gaya pacaran remaja, akibatnya remaja cenderung melakukan hubungan seksual pranikah. ${ }^{10}$

Penelitian ini mendapat hasil yang sama dengan penelitian Christine Ohee di Surabaya mengenai status pacaran dengan perilaku seksual berisiko (2017). Hasil proporsi responden yang melakukan pacaran berisiko dengan status sedang berpacaran $(93,5)$, yang tidak berpacaran dan melakukan pacaran berisiko $(30,8 \%)$, dan yang melakukan pacaran berisiko dengan pacaran jarak jauh (36,4\%). Artinya bahwa mahasiswa perantau asal Papua yang sedang berpacaran lebih banyak melakukan pacaran berisiko, sehingga status berpacaran berisiko terhadap perilaku pacaran. ${ }^{18}$

Menurut peneliti dari hasil penelitian ada hubungan antara status pacaran dengan perilaku seksual berisiko pada siswa dikarenakan Berpacaran merupakan gerbang menuju melakukan hubungan seksual, Remaja cenderung memilih untuk berpacaran ketika berada di bangku sekolah sebagai penyemangat untuk belajar dll, berpacaran membuat seseorang tersebut meiliki hasrat seksual anatara kedua lawan jenis akan mepengaruhi terjadinya hubungan seksual, karena hasrat hubungan seksual timbul kapan saja dan dimana saja, tergantung bagaimana bisa mengontrol diri.

\section{Hubungan Kontrol Orang Tua Dengan Perilaku Pacaran Yang Berisiko Pada Siswa Di}


SMKS YP Darul Mukminin Jatinegara Jakarta Timur Tahun 2020

Berdasarkan hasil penelitian bahwa antara peran orang tua dengan perilaku seksual berisiko pada siswa didapatkan Hasil uji chisquare diperoleh nilai $p$ value 0,665 maka dapat disimpulkan tidak ada hubungan yang signifikan antara peran orang tua dengan perilaku seksual berisiko.

Menurut Retnowati (2010), Ketidak tahuan orang tua maupun sikap yang masih menabukan pembicaraan seks dengan anak bahkan cenderung membuat jarak dengan anak. Akibatnya pengetahuan remaja tentang seksualitas sangat kurang. Padahal kontrol orang tua sangatlah penting, terutama pemberian pengetahuan tentang seksualitas. Perilaku seksual merupakan salah satu bentuk pelampiasan kekesalan serta orang dewasa yang dianggap terlalu banyak mengatur atau mengekang dan ketidak puasan remaja terhadap orangtua. Dalam berbagai penelitian yang telah dilakukan, dikemukakan bahwa anak/remaja yang tidak di control oleh orang tua nya dan dibesarkan dalam lingkungan sosial berperilaku menyimpang lebih besar dibandingkan dengan anak/remaja yang di kontrol oleh orang tua nya dan dibesarkan dalam keluarga sehat/harmonis, maka resiko anak untuk mengalami gangguan kepribadian menjadi berkepribadian antisosial. ${ }^{19}$

Penelitian ini mendapat hasil yang berbeda dengan penelitian Harni Andriani, Yasnani, Arum yang di Kendari (2016). Mengenai hubungan kontrol orang tua dengan perilaku pacaran yang beresiko.Berdasarkan hasil analisis statistic Continuity Correction diperoleh nilai P atau nilai signifikansi adalah 0,040 dan $\alpha$ adalah 0,05 . nilai $P$ lebih kecil dari $\alpha$, maka hipotesis $H 0$ ditolak dan Ha diterima yaitu ada hubungan antara peran keluarga dengan perilaku seksual. Adapun berdasarkan analisis uji keeratan hubungan diperoleh nilai Phi $(\varnothing)=0,328$. Angka tersebut menunjukkan hubungan yang sedang karena terletak antara 0,26-0,50. Dengan demikian dapat diinterpretasikan bahwa variabel peran keluarga mempunyai hubungan yang sedang dengan perilaku pacaran pada siswa SMK Negeri 1 Kendari Kota Kendari Tahun 2016. ${ }^{12}$

Menurut peneliti dari hasil penelitian tidak adanya hubungan peran orang tua dengan perilaku seksual berisiko pada siswa dikarenakan tidak semua siswa di tempat penelitian $100 \%$ diawasi orang tua, karena ada yang ngekost dll tetapi peran aktif orang tua dalam berkomunikasi dengan anaknya memiliki peranan yang penting dalam membentuk karakter anak dan perilaku anak selain itu komunikasi yang baik akan meberikan gambaran atau pandangan mengenai pemaknaan seks yang benar sehingga anak mengerti batasan yang baik dan tidak baik untuk mereka.

8. Hubungan Informasi Pendidikan kesehatan di Sekolah Dengan Perilaku Seksual Berisiko Pada Siswa Di SMKS YP Darul Mukminin Jatinegara Jakarta Timur Tahun 2020

Berdasarkan hasil penelitian bahwa antara pendidika kesehatan di sekolah dengan perilaku pacaran yang berisiko pada siswa didapatkan, Hasil uji chi-square diperoleh nilai $p$ value 0,596 maka dapat disimpulkan tidak ada 
hubungan yang signifikan antara pendidikan kesehatan disekolah dengan perilaku seksual berisiko.

Menurut teori Evi (2014) untuk mencegah perilaku beresiko pada seksual remaja yang tidak terarah. Untuk memperoleh informasi tersebut peran sekolah dalam pendidikan kesehatan. melalui usaha kesehatan sekolah (UKS) atau dari sekolah misalnya bisa melalui peran konseling (BK), Sedangkan peran guru BK yang sekaligus menjadi orang tua siswa-siswi selama dilingkungan sekolah yaitu dengan memberikan pemahaman supaya tidak melakukan hubungan seksual sebelum menikah. $^{20}$

Penelitian ini berbeda dengan penelitian Nadra anniswah (2016). Mengenai hubungan pendidikan kesehatan disekolah dengan perilaku pacaran yang beresiko. Berdasarkan hasil analisis diperoleh $p$ value 0,025 yang berarti terdapat hubungan yang signifikan antara pendidikan di sekolah dengan prilaku pacaran yg beresiko. ${ }^{13}$

Menurut peneliti dari hasil penelitian ada hubungan pendidikan di sekolah dengan perilaku pacaran yang berisiko pada siswa dikarenakan hal ini materi kesehatan reprodusi sudah mulai dimasukan kedalam kurikulum pendidikan, Sehingga siswa tau apa itu kesehatan reproduksi dan bahaya dari perilaku seksual yg beresiko. Tidak haya intitusi pendidikan resmi saja, Di harap kan berbagai pihak ikut membantu meningkatkan pemahaman terkait kesehatan reproduksi yang komprehensif pada remaja.

\section{Hubungan Teman Sebaya Dengan} Perilaku Pacaran Yang Berisiko Pada Siswa Di

\section{SMKS YP Darul Mukminin Jatinegara Jakarta} Timur Tahun 2020

Berdasarkan hasil penelitian bahwa antara teman sebaya dengan perilaku pacaran yang berisiko pada siswa didapatkan . Hasil uji chi-square diperoleh nilai $p$ value 0,047 maka dapat disimpulkan ada hubungan yang signifikan antara teman sebaya dengan perilaku pacaran yang berisiko. Diperoleh nilai OR 0,370 yang artinya siswa yang terpengaruh teman sebaya mempunyai risiko untuk berperilaku pacaran beresiko 0,3 kali lebih besar dibandingkan siswa yang tidak terpegaruh teman sebaya.

Menurut (Santrock, 2013), Remaja mulai belajar mengenai pola hubungan yang timbal balik dan setara melalui interaksi dengan teman sebaya. Mereka juga belajar untuk mengamati dengan teliti minat dan pandangan teman sebaya dengan tujuan untuk memudahkan proses penyatuan dirinya ke dalam aktifitas teman sebaya yang sedang berlangsung. Pada banyak remaja, bagaimana mereka dipandang oleh teman sebaya merupakan hal yang terpenting dalam kehidupan. ${ }^{2}$

Penelitian ini mendapat hasil yang sama dengan penelitian Yulianti, Nia, Suratini (2015). Mengenai teman sebaya dengan perilaku seksual berisiko. Hasil uji Fisher exact menunjukkan adanya hubungan yang signifikan antara pergaulan teman sebaya dengan perilaku pacaran pada siswa kelas XI IPS di SMA Negeri 1 Semin Gunung Kidul Yogyakarta $(<0,05) \cdot{ }^{21}$

Menurut peneliti dari hasil penelitian bahwa ada hubungan teman sebaya dengan perilaku pacaran yang berisiko pada siswa 
dikarenakan Teman/sahabat sebaya adalah teman yang berada pada usia yang sama dan diantara mereka biasanya terjalin keakraban. Peranan teman/sahabat sebaya pada remaja sangat besar dalam kehidupan remaja seharihari. Gaya berpacaran teman sebaya menjadi model atau acuan yang digunakan seseorang remaja dalam pacaran. Teman biasa melakukan ciuman dengan pacarnya, maka dibenarkan kalau dia juga berciuman. Pengaruh teman sebaya menjadi suatu jalinan ikatan yang sangat kuat. Remaja lebih banyak berada diluar rumah bersama teman-teman sebaya sebagai kelompok.

10. Hubungan Media Informasi Dengan Perilaku Seksual Berisiko Pada Siswa Di SMKS YP Darul Mukminin Jatinegara Jakarta Timur Tahun 2020

Berdasarkan hasil penelitian bahwa antara teman sebaya dengan perilaku pacaran yang berisiko pada siswa didapatkan, Hasil uji chisquare diperoleh nilai $p$ value 1,000 maka dapat disimpulkan tidak ada hubungan yang signifikan antara media informasi dengan perilaku seksual berisiko.

Menurut teori Soetjiningsih (2010) media informasi baik media cetak maupun media elektronik banyak menampilkan seksualitas sacara vulgar yang dapat merangsang birahi terutama remaja, Media baik elektronik mapun cetak saat ini banyak disorot sebagai salah satu penyebab utama menurunnya moral umat manusia termasuk juga remaja. ${ }^{22}$

Penelitian ini berbeda dengan penelitian Harni Andriani, Yasnani, Arum yang di Kendari (2016). Mengenai hubungan media informasi dengan perilaku pacaran yang beresiko. Hasil analisis statistik Fisher's Exact Test diperoleh nilai $P$ atau nilai signifikansi adalah 0,010 dan $\alpha$ adalah 0,05 . nilai P lebih kecil dari $\alpha$, maka hipotesis $\mathrm{HO}$ ditolak dan $\mathrm{Ha}$ diterima artinya terdapat hubungan antara akses media informasi dengan perilaku seksual. Adapun berdasarkan analisis uji keeratan hubungan diperoleh nilai Phi $(\varnothing)=$ 0,496 . Angka tersebut menunjukkan hubungan yang sedang karena terletak antara 0,260,50.Dengan demikian dapat diinterpretasikan bahwa akses media informasi mempunyai hubungan yang sedang dengan perilaku seksual siswa SMK Negeri 1 Kendari Kota Kendari Tahun $2016 .^{21}$

Menurut peneliti dari hasil penelitian tidak ada hubungan media informasi dengan perilaku pacaran yang berisiko pada siswa dikarenakan Rasa ingin tahu pada remaja tentang suatu hal sangat tinggi, sumber informasi yang mudah mereka jangkau adalah teman teman dan media (VCD porno, akses internet). Hampir setiap remaja memiliki handphone, laptop, dan media elektronik lainnya,Sehingga semakin siswa banyak mengakses tentang pornografi pada media eletronik, cetak dll semakin tahu mengenai seksual beresiko dan berkeinginan melakukan prilaku pacaran yang beresiko atau menyalurkan hasrat seksualnya.

\section{Hasil Analisis multivariat}

a. Hasil Akhir

Pembuatan model akhir bertujuan untuk menyimpulkan variabel penentu yang membuktikan determinan prilaku pacaran yang beresiko. Model akhir analisis multivariate. 
Permodelan Multivariat Akhir

\begin{tabular}{llll}
\hline No & Variebel & $\boldsymbol{P}$ Value & OR \\
\hline $\mathbf{1}$ & Jenis Kelamin & 0,272 & 0,160 \\
\hline $\mathbf{2}$ & Teman Sebaya & 0,462 & 2,648 \\
\hline $\mathbf{3}$ & Pengetahuan & 0,900 & 0,891 \\
\hline $\mathbf{4}$ & Status pacaran & 0,747 & 0,754
\end{tabular}

b. Variabel Dominan

Hasil analisis multivariat dihasilkan bahwa jenis kelamin, teman sebaya, pengetahuan dan status pacaran merupakan variabel confounding. Hasil analisis didapatkan Odds Ratio (OR) dari variabel teman sebaya adalah 2,648 artinya siswa yang terpengaruh teman sebaya mempunyai risiko untuk berperilaku pacaran yang beresiko 2,6 kali lebih besar dibandingkan siswa yang tidak terpengaruh teman sebaya. Jadi variabel yang dominan berhubungan dengan perilaku pacaran yang berisiko pada siswa adalah pengaruh teman sebaya. $^{12}$

\section{KESIMPULAN}

Dari hasil penelitian "determinan perilaku pacaran yang beresiko pada siswa SMKS YP Darul Mukminin Jatinegara Jakarta timur tahun 2020", dapat disimpulkan sebagai berikut,Sekitar siswa $(24,8 \%)$ memiliki perilaku seksual berisiko dan Sekitar siswa $(75,2 \%)$ memiliki perilaku seksual tidak berisiko. Variabel yang mempunyai hubungan dengan perilaku seksual beresiko dari variable independen yaitu Pengetahuan, Jenis kelamin, Tempat tinggal, Status pacaran dan pengaruh teman sebaya. Walaupun tidak bermakna secara statistik, Variabel yang dominan yang berhubungan dengan perilaku pacaran beresiko adalah Teman sebaya dengan Odds Ratio (OR) adalah 2,648 setelah dikontrol oleh variable Pengetahuan,jenis kelamin, status pacaran dan tempat tinggal. Variable yang tidak berhubungan dengan perilaku seksual beresiko yaitu variable Sikap, Kontrol orang tua, Pendidikan kesehatan disekolah dan pengaruh media informasi.

\section{DAFTAR PUSTAKA}

Sarwono, S.W. (2012). Psikologi Remaja. Jakarta: PT Raja Grafindo Persada.

1. Santrock, J.W. (2013). Adolescence (perkembangan remaja). Erlangga. Jakarta.

2. BPS, BKKBN, Kemenkes dan ICF International. 2013. Survei Demografi dan Kesehatan Indonesia 2012 Kesehatan Reproduksi Remaja. Jakarta: BPS. BKKBN, Kemenkes dan ICF International.

3. Anonim. (2014). Empat puluh enam persen remaja terlibat sex pranikah, remaja rentan terhadap godaan, aborsi dan penyakit seksual. Diakses dari http://www.bkkbn.go.id/ViewBerita.aspx ?BeritaID=1764, pada 27 Februari 2020.

4. Anonim, (2014). Penderita AIDS di Indonesia 5,686 dan HIV 21.511 orang. Diakses dari http://m.detik.com/news/read/2013/04/ 03/122856/2210317/466/penderita-aidsdiindonesia-5686-dan-hiv-2151-orang, pada 16 Februari 2020. 
5. Survey Kesehatan Reproduksi Remaja Indonesia. 2012. Kesehatan Reproduksi Remaja. Badan Kependudukan dan Keluarga Berencana. Badan Pusat Statistik. Kementrian Kesehatan. MEASURE DHS. ICF Internasional. Jakarta. Agustus 2013.

6. Notoadmodjo, S. 2010. Metodologi Penelitian Kesehatan. Jakarta: Rineka Cipta.

7. Notoadmodjo, S. 2012. Metodologi Penelitian Kesehatan. Jakarta: Rineka Cipta.

8. Hastono, Sutanto Priyo. 2016. Analisa Data Pada Bidang Kesehatan. Jakarta: Raja Grafindo Persada.

9. Iwan. 2010. Masturbasi. Yogyakarta: C.V Andi Ofset.

10. Mahmudah $M$, Yaslinda $Y$, Yuniar L. Faktor-Faktor Yang Berhubungan Dengan Perilaku Seksual Remaja di Kota Padang. Sumatra Barat. 2016.

11. Harni A, Yasni Y, Arum DP. Hubungan Pengetahuan, Akses Media Informasi dan Peran Keluarga Terhadap Perilaku Seksual Pada Siswa SMK Negri 1 Kendari Tahun 2016. Vol 1, No 3. 2016.

12. Nadra Anniswah. Faktor-Faktor Yang Berhubungan Dengan Perilaku Seksual Beresiko IMS Pada Remaja Pria Di Indonesia. (Analisi Data Survei Demografi dan Kesehatan Indonesia Tahun 2012). Jakarta. 2016.

13. Saifuddin, A. 2014. Buku Panduan Praktis Pelayanan Kesehatan Maternal dan
Neonatal. Jakarta: Yayasan BIna Pustaka Sarwono Prawiharohardjo.

14. Anak Agung P.A.R.W.W, Ni Wayan C.W.S.P. Hubungan Antara Jenis Kelamin dan Status Sosioekonomi Keluarga Terhadap Seks Pranikah Pada Remaja SMA/Sederajat Di Wilayah Kerja Puskesmas Sukawati Pada Tahun 2014. Vol 4 no 9. 2015.

15. PKBI. (2015). Macam-Macam Perilaku Seksual. Yogyakarta.

16. Erna, M. Pengaruh Teman Sebaya Terhadap Perilaku Seksual Remaja. 2016.

17. Christine, O, Windhu, P. Pengaruh Status Hubungan Berpacaran Terhadap Perilaku Pacaran Beresiko Pada Mahasiswa Perantau Asal Papua Di Kota Surabaya. 2017. Vol 13, no 2. 2018.

18. Retnowati, E., Ayres, P., \& Sweller, J. (2010). Worked example effects in individual and group work setting. Educational Psychology, 30(3), 349-367.

19. Evi, Nasir., S, dam Suriah. (2014). Perilaku Seksual Pada Remaja Yang Berpacaran Di SMA Negeri 2 Karatau Kabupaten Serau Bagian Barat.

20. Yulianti, Nia, Suratini. Hubungan Pergaulan Teman Sebaya Dengan Perilaku Seksual Remaja Pada Siswa Kelas XI IPS Di SMK N 1 Semin Gunungkidul Yogyakarta. 2015.

21. Soetjiningsih. 2010. Tumbuh Kembang Remaja dan Permasalahannya. Jakarta: Sagung Seto. 